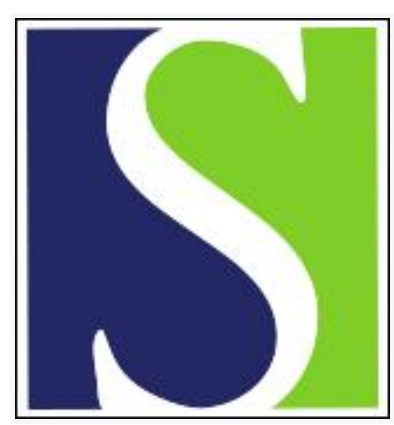

Scand J Work Environ Health 1987;13(2):124-128

https://doi.org/10.5271/sjweh.2071

Issue date: Apr 1987

Mortality among male farmers in Finland during 1979-1983.

by Notkola VJ, Husman KR, Laukkanen VJ

This article in PubMed: www.ncbi.nlm.nih.gov/pubmed/3602966

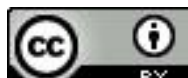




\title{
Mortality among male farmers in Finland during 1979-1983
}

\author{
by Veijo J Notkola, PhD, MSc, Kaj RH Husman, MD, MSc, Vesa J Laukkanen, MSc ${ }^{1}$
}

\begin{abstract}
NOTKOLA VJ, HUSMAN KRH, LAUKKANEN VJ. Mortality among male farmers in Finland in 1979-1983. Scand J Work Environ Health 13 (1987) 124-128. In this study the cause-specific mortality of male farmers in Finland was compared with the mortality of all economically active men. Mortality was also examined by size of farm, by type of farm production, and by geographic area. It was shown that, compared to the mortality of all economically active men, that of the farmers was generally low. The only exception was mortality due to respiratory diseases, for which the mortality rate of the farmers was about $40-50 \%$ higher than that of all economically active men. The rate ratio, which was higher for those men with small farms, was almost independent of the cause of death. The rate ratio was highest for farmers in eastern and northern Finland. Assessed by type of farm production, the differences in mortality were small. It was supposed that the high rate ratio of respiratory deaths among farmers was, at least partly, work-related. The high mortality of the men with a small farm was shown to be associated with the higher proportion of smokers among this group of farmers.
\end{abstract}

Key terms: work-related respiratory diseases.

Several occupational epidemiologic studies suggest that the mortality of farmers is generally lower than the average mortality rate for economically active men (4). In earlier studies carried out in Finland the same conclusion had been reached. In a study of mortality according to occupation based on official statistics, the total mortality for agriculture and forestry management [standardized mortality ratio (SMR) 91] in 1971-1975 was lower than the average rate for economically active men in Finland (15). This result was also confirmed in an epidemiologic study based on data from the "Seven Country Study" (11).

Those few studies in which the morbidity of farmers in Finland has been analyzed according to occupation have pointed out that the morbidity of the farming population is higher than that of other occupational groups $(2,7,16)$.

Although in international studies the total mortality of farmers has been lower than average, the SMR values of some specific causes of death have been high for farmers. Farmers have been shown to have elevated risks of certain types of cancer, ie, cancer of the lymphatic and hematopoietic system, stomach, prostate, brain, lip, skin and connective tissue (4).

In Sauli's study (15) in Finland fairly high SMR values were determined for the cause-specific mortality groups of cancer of the prostate (SMR 115), bronchitis, emphysema and asthma (SMR 135), and nephritic diseases (SMR 129). In the same study the occupational group "farmers" was broken down into two groups, ie, those on small and those on large farms; and it was

\footnotetext{
1 Kuopio Regional Institute of Occupational Health, Kuopio, Finland.
}

Reprint requests to: Dr VJ Notkola, Kuopio Regional Institute of Occupational Health, PO Box 93, SF-70701 Kuopio, Finland. observed that the mortality rate of men with small farms (2-9.9 ha) was generally higher from all specific causes of death than that for farmers with more land. The greatest relative difference in mortality was found for the bronchitis, emphysema and asthma group, in which mortality was approximately $70 \%$ higher for farmers with 2-9.9 ha than for farmers with more than 10 ha (15).

The first aim of this study was to compare the causespecific mortality of male farmers in Finland during 1979-1983 to the mortality of all economically active men. The second aim was to analyze the variation in the mortality of male farmers in relation to the type of farm production, the size of the farm, and the geographic area in which the farm was located.

\section{Subjects and methods}

This study was based on the Finnish farm register. The male population included in the farm register on 31 December 1978 was defined as the population at risk. The Finnish farm register was founded on the basis of the information from the general farm calculation of 1969 , to be used in forming a basic register for official farm statistics. All those persons or corporations owning farms were included in the register, in which a farm refers to the totality of cultivated land that has a field and garden area which surpasses 1 ha. Information is collected each year with a postal questionnaire.

Information about the owner, occupation of the owner, and size of the farm was taken from the 31 December 1978 farm register. Information concerning the type of farm was collected separately from the $31 \mathrm{De}-$ cember 1977 farm register. The farm register is basically reliable. For example, it was used as part of the 
1980 Finnish Population and Housing Census (13).

Data on all deaths during 1979-1983, causes of death, etc, were obtained from death certificate data recorded in the Finnish register on causes of death. For the classification of deaths the International Classification of Diseases (ICD), eighth revision, was used. Only the underlying cause of death was available in the data for causes of death.

The following causes of death were considered: all diseases (ICD-8, 1-799), cardiovascular diseases (ICD-8, 390-459), neoplasms (ICD-8, 140-239), diseases of the respiratory system (ICD-8, 460-519), and accidents, poisonings and violence (ICD-8, 800-999).

Only the active men aged $35-64$ years whose occupation was listed in the farm register as farmer were included. The study population thus defined numbered 100435 persons. Women could not be included in the study population because the registered owner of the farm was, in most cases, male.

The data by type of farming were classified as follows: (i) farms, no animals, (ii) dairy farms (fewer than 10 pigs or chickens), (iii) pig farms (no other animals), (iv) poultry farms (egg or chicken production, no other animals), and (v) other animal husbandry.

Farm size was classified by cultivated land owned or rented into the following five different classes: $1-4.9$ ha, $5-9.9$ ha, $10-14.9$ ha, $15-19.9$ ha, and $\geq 20$ ha.

The farmers were classified by age into five-year age categories at the beginning of the follow-up on 1 January 1979.

The geographic location of the farm was classified as follows (11): western Finland (provinces of Turku and Pori, Ahvenanmaa, and Vaasa), southern Finland (provinces of Uusimaa and Kymi), middle Finland (provinces of Häme and Keski-Suomi), eastern Finland (provinces of Mikkeli, Kuopio and PohjoisKarjala), and northern Finland (provinces of Oulu and Lappi).

For each explanatory independent variable, the number of follow-up years was calculated. In the estimation of the rate ratios a log-linear model was used. The aim was to analyze the independent effect of different explanatory categories on the mortality of the farmers, and therefore the effect of possible significant factors such as age and geographic location were taken into account by the use of a log-linear model. The estimation of relative risks was made with the use of the Poisson model $(3,5)$. The statistical significance of the mortality differences between the categories was tested with likelihood ratio statistics (asymptotic chi-squared deviances).

Use of a log-linear model made it possible to adjust the effect of different variables at the same time. It was also possible to analyze the effect of interaction between different variables.

Because of the small numbers of deaths, the agestandardized mortality rates have been calculated with the use of indirect age standardization (1).

\section{Results}

Mortality of farmers in comparison to that of all economically active men

The mortality comparison between farmers (1979-1983) and all economically active men in Finland (1976-1980) showed that the mortality of the farmer was clearly lower than that of the latter (table 1). Although, in general, the mortality of farmers was low, those with diseases of the respiratory system were exceptions. In this group the mortality of farmers was about $40-50 \%$ higher than that for all economically active men.

\section{Regional mortality differences among male farmers in Finland 1979-1983}

As shown in table 2, for the mortality of male farmers, there were considerable differences between the different regions. The risks were highest in eastern and northern Finland. The lowest rate ratios were usually found in western and southern Finland.

In the analysis of the differences in mortality according to the causes of death (table 2), only in the case of cardiovascular diseases were the regional mortality differences among farmers significant. Owing to the regional differences in mortality among farmers, however, the effect of the variable "geographic location" was taken into account when the effects of the variables "size of farm" and "type of farming" were analyzed, and in the consideration of the interaction effects as well.

\section{Mortality differences by size of farm}

As presented in table 3 , the rate ratio was almost always the highest among owners of small farms. The rate ratio due to all diseases was about $30 \%$ higher among small-farm owners than among farmers having over 20 ha of cultivated land. It also seemed that the relationship between farm size and mortality was linear. The picture was the same for the case of cardiovascular diseases, for accidents, poisonings and violence, and for diseases of the respiratory system, although, owing to the small number of deaths, the dif-

Table 1. Mortality by cause of death in 1979-1983 among male rarmers aged 35-64 years on the basis of farm register data with the data on all economically active males in Finland in $1976-1980$ as reference. $(O=$ observed number of deaths, $E$ $\doteq$ expected number of deaths, SMR = standardized mortality ratio, $95 \% \mathrm{Cl}=95 \%$ confidence interval).

\begin{tabular}{lrrrc}
\hline & O & E & SMR & $95 \% \mathrm{Cl}$ \\
\cline { 2 - 5 } Total mortality & 4361 & 4788 & 91 & $90-92$ \\
All diseases & 3901 & 4178 & 93 & $92-95$ \\
Cardiovascular diseases & 2491 & 2589 & 96 & $94-98$ \\
Diseases of the respiratory system & 163 & 111 & 147 & $135-159$ \\
Neoplasms & 1020 & 1201 & 85 & $82-88$ \\
Accidents, poisonings and violence & 460 & 609 & 76 & $69-83$ \\
\hline
\end{tabular}


Table 2. Rate ratio (RR) of death by causes of death and location of farm in Finland, 1979-1983 (male farmers aged $35-64$ years), adjusted for age. ( $\mathrm{N}=$ number of deaths, $\mathrm{NS}=$ not significant)

\begin{tabular}{|c|c|c|c|c|c|c|c|c|c|c|c|c|}
\hline \multirow{2}{*}{$\begin{array}{l}\text { Cause } \\
\text { of } \\
\text { death }\end{array}$} & \multicolumn{2}{|c|}{$\begin{array}{l}\text { Western } \\
\text { Finland }\end{array}$} & \multicolumn{2}{|c|}{$\begin{array}{l}\text { Southern } \\
\text { Finland }\end{array}$} & \multicolumn{2}{|c|}{$\begin{array}{l}\text { Middle } \\
\text { Finland }\end{array}$} & \multicolumn{2}{|c|}{$\begin{array}{l}\text { Eastern } \\
\text { Finland }\end{array}$} & \multicolumn{2}{|c|}{$\begin{array}{l}\text { Northern } \\
\text { Finland }\end{array}$} & \multirow[t]{2}{*}{$\chi^{2}(d f=4)$} & \multirow[t]{2}{*}{$P$} \\
\hline & $\mathrm{N}$ & $\mathrm{RR}$ & $\mathrm{N}$ & $\mathrm{RR}$ & $\mathrm{N}$ & RR & $\mathrm{N}$ & RR & $N$ & $\mathrm{RR}$ & & \\
\hline All diseases & 1242 & 100 & 472 & 116 & 620 & 114 & 900 & 132 & 667 & 131 & 56.2 & $<0.001$ \\
\hline Cardiovascular diseases & 763 & 100 & 307 & 123 & 387 & 116 & 591 & 142 & 444 & 143 & 57.4 & $<0.001$ \\
\hline Diseases of the respiratory system & 56 & 100 & 21 & 118 & 29 & 120 & 38 & 128 & 19 & 85 & 3.0 & NS \\
\hline Neoplasms & 364 & 100 & 120 & 101 & 160 & 100 & 226 & 113 & 172 & 116 & 4.6 & NS \\
\hline $\begin{array}{l}\text { Accidents, poisonings and } \\
\text { violence }\end{array}$ & 145 & 100 & 55 & 112 & 69 & 106 & 119 & 143 & 72 & 120 & 8.9 & NS \\
\hline
\end{tabular}

a Reference group.

Table 3. Rate ratio (RR) of death by cause of death and size of farm, adjusted for age and location of farm. $(\mathbf{N}=$ number of deaths, NS = not significant)

\begin{tabular}{|c|c|c|c|c|c|c|c|c|c|c|}
\hline \multirow[t]{2}{*}{$\begin{array}{l}\text { Size of } \\
\text { farm } \\
\text { (ha) }\end{array}$} & \multicolumn{2}{|c|}{$\begin{array}{c}\text { All } \\
\text { diseases }\end{array}$} & \multicolumn{2}{|c|}{$\begin{array}{l}\text { Cardio- } \\
\text { vas- } \\
\text { cular } \\
\text { dis- } \\
\text { eases }\end{array}$} & \multicolumn{2}{|c|}{$\begin{array}{l}\text { Dis- } \\
\text { eases } \\
\text { of the } \\
\text { respi- } \\
\text { ratory } \\
\text { sys- } \\
\text { tem }\end{array}$} & \multicolumn{2}{|c|}{$\begin{array}{l}\text { Neo- } \\
\text { plasms }\end{array}$} & \multicolumn{2}{|c|}{$\begin{array}{c}\text { Acci- } \\
\text { dents, } \\
\text { poiso- } \\
\text { nings } \\
\text { and } \\
\text { vio- } \\
\text { lence }\end{array}$} \\
\hline & $\mathbf{N}$ & RR & $\mathbf{N}$ & $\mathrm{RR}$ & $N$ & RR & $N$ & RR & $\mathrm{N}$ & $\mathrm{RR}$ \\
\hline$\geq 20^{a}$ & 486 & 100 & 305 & 100 & 20 & 100 & 129 & 100 & 68 & 100 \\
\hline $15-19.9$ & 432 & 2117 & 267 & 114 & 13 & 84 & 128 & 131 & 60 & 126 \\
\hline $10-14.9$ & 828 & 3118 & 536 & 121 & 34 & 115 & 209 & 113 & 94 & 114 \\
\hline $5-9.9$ & 150 & 132 & 965 & 132 & 65 & 132 & 409 & 137 & 170 & 145 \\
\hline $1-4.9$ & 65 & 151 & 418 & 152 & 31 & 161 & 167 & 149 & 68 & 172 \\
\hline
\end{tabular}

Effect of size of farm:

$\begin{array}{lccccc}\chi^{2}(\mathrm{df}=4) & 53.8 & 35.5 & 5.3 & 16.2 & 12.5 \\ \mathrm{P} & <0.001 & <0.001 & \mathrm{NS} & <0.01 & <0.05\end{array}$

Effect of the interaction:

\begin{tabular}{llllll}
$\begin{array}{l}\text { Age and size } \\
\text { of farm }\end{array}$ & & & & & \\
$\chi^{2}(\mathrm{df}=20)$ & 19.3 & 24.2 & 12.8 & 10.4 & 16 \\
$\mathrm{P}$ & $\mathrm{NS}$ & $\mathrm{NS}$ & $\mathrm{NS}$ & $\mathrm{NS}$ & NS \\
& & & & & \\
Location and & & & & & \\
size of farm & & & & & \\
$\chi^{2}(\mathrm{df}=16)$ & 17.8 & 11.5 & 12.7 & 27.2 & 10.5 \\
$\mathrm{P}$ & $\mathrm{NS}$ & $\mathrm{NS}$ & $\mathrm{NS}$ & 0.05 & $\mathrm{NS}$ \\
\hline
\end{tabular}

a Reference group.

ferences in rate ratios due to diseases of the respiratory system were not statistically significant. The rate ratio for neoplasms was also the highest among men with small farms.

\section{Mortality differences by type of farming}

When the differences in the rate ratios by type of farming were compared to the differences by size of farm, the differences in mortality were much smaller for type of farming (table 4). Statistically, the differences by type of farming were only significant for all diseases, for cardiovascular diseases, and for accidents, poisonings and violence. Although in most cases the differences were not statistically significant, the rate ratio was, independently of the cause of death, almost always the highest among farmers with no animals.
The adjustment for size of farm caused a decline in the differences in mortality found by type of farming (table 4, lower part). The rate ratio due to cardiovascular diseases was, however, still high among farmers with no animals.

\section{Interaction effects}

According to the results shown in tables 3 and 4, the interaction effects were negligible. Mortality differences by size of farm were the same in different age groups and in different areas. In addition, there were no interaction effects between the size of the farm and type of farming. The mortality of men with small farms was highest in all types of farm production independently of the cause of death. Only in the case of age and type of farm was there an interaction effect between the variables.

\section{Discussion}

In previous studies in Finland, and also in other countries, it has been shown that the mortality of male farmers is generally low compared to that of all economically active men. In this study the same conclusion could be drawn. Compared to the mortality of all economically active men, that of male farmers was, on an average, $10-30 \%$ lower. The only exception was the mortality due to respiratory diseases, for which the mortality rate of male farmers was about $40-50 \%$ higher than that of all economically active men.

Although, in general, the farmers' mortality was low, the mortality of those with small farms was clearly higher than that of other farmers and higher than the mortality of all economically active men. As measured by the SMR, also for owners of larger farms (> 15 ha), the mortality due to respiratory diseases was higher (SMR 110) than that for all economically active men.

The mortality of men with small farms was high in every type of farm production. Almost independently of the cause of death, the mortality among smallfarm owners in Finland was found to be higher than that among those with larger farms. Disability studies among the farming population have also shown that 
Table 4. Rate ratio (RR) of death by cause of death and by type of farming. ( $N=$ number of deaths, $N S=$ not significant)

\begin{tabular}{|c|c|c|c|c|c|c|c|c|c|c|}
\hline \multirow[t]{2}{*}{$\begin{array}{l}\text { Type of } \\
\text { farm }\end{array}$} & \multicolumn{2}{|c|}{$\begin{array}{c}\text { All } \\
\text { diseases }\end{array}$} & \multicolumn{2}{|c|}{$\begin{array}{l}\text { Cardio- } \\
\text { vascular } \\
\text { diseases }\end{array}$} & \multicolumn{2}{|c|}{$\begin{array}{l}\text { Diseases } \\
\text { of the } \\
\text { respiratory } \\
\text { system }\end{array}$} & \multicolumn{2}{|c|}{$\begin{array}{l}\text { Neo- } \\
\text { plasms }\end{array}$} & \multicolumn{2}{|c|}{$\begin{array}{l}\text { Accidents, } \\
\text { poisonings } \\
\text { and } \\
\text { violence }\end{array}$} \\
\hline & $\mathrm{N}$ & RR & $\mathrm{N}$ & $\mathrm{RR}$ & $\mathrm{N}$ & RR & $\mathrm{N}$ & RR & $\mathbf{N}$ & $\mathrm{RR}$ \\
\hline \multicolumn{11}{|c|}{ Adjusted for age and location of farm } \\
\hline Farm, no animals ${ }^{a}$ & 1002 & 100 & 637 & 100 & 40 & 100 & 265 & 100 & 134 & 100 \\
\hline Dairy farms & 2422 & 85 & 1554 & 86 & 102 & 54 & 648 & 87 & 170 & 64 \\
\hline Pig farms & 102 & 72 & 58 & 66 & 3 & 54 & 35 & 90 & 94 & 67 \\
\hline Poultry farms & 131 & 84 & 89 & 92 & 6 & 88 & 32 & 75 & 60 & 99 \\
\hline Other animal husbandry & 244 & 81 & 153 & 81 & 12 & 98 & 62 & 77 & 68 & 71 \\
\hline \multicolumn{11}{|l|}{ Effect of type of farm: } \\
\hline$\chi_{\mathrm{P}}^{2}(\mathrm{df}=4)$ & \multicolumn{2}{|c|}{$\begin{array}{c}29.7 \\
<0.001\end{array}$} & \multicolumn{2}{|c|}{$\begin{array}{l}17.7 \\
<0.01\end{array}$} & \multicolumn{2}{|c|}{$\begin{array}{l}1.3 \\
\text { NS }\end{array}$} & \multicolumn{2}{|c|}{$\begin{array}{l}6.0 \\
\text { NS }\end{array}$} & \multicolumn{2}{|c|}{$\begin{array}{l}18.3 \\
<0.01\end{array}$} \\
\hline \multicolumn{11}{|c|}{ Adjusted for age, location of farm and size of farm } \\
\hline Farm, no animals ${ }^{a}$ & 1002 & 100 & 637 & 100 & 40 & 100 & 265 & 100 & 134 & 100 \\
\hline Dairy farms & 2422 & 88 & 1554 & 89 & 102 & 99 & 648 & 89 & 170 & 66 \\
\hline Pig farms & 102 & 79 & 58 & 72 & 3 & 62 & 35 & 98 & 94 & 74 \\
\hline Poultry farms & 131 & 88 & 89 & 96 & 6 & 93 & 32 & 78 & 60 & 104 \\
\hline Other animal husbandry & 244 & 85 & 153 & 85 & 12 & 95 & 62 & 80 & 68 & 75 \\
\hline \multicolumn{11}{|l|}{ Effect of type of farm: } \\
\hline$\chi_{P}^{2}(d f=4)$ & \multicolumn{2}{|c|}{$\begin{array}{r}13.6 \\
<0.01\end{array}$} & \multicolumn{2}{|c|}{$\begin{array}{l}10.0 \\
<0.05\end{array}$} & \multicolumn{2}{|c|}{$\begin{array}{l}0.8 \\
\text { NS }\end{array}$} & \multicolumn{2}{|c|}{$\begin{array}{l}4.4 \\
\text { NS }\end{array}$} & \multicolumn{2}{|c|}{$\begin{array}{l}15.3 \\
<0.01\end{array}$} \\
\hline \multicolumn{11}{|l|}{$\begin{array}{l}\text { Effect of interaction: } \\
\text { Age and type of farm }\end{array}$} \\
\hline$\chi_{P}^{2}(d f=20)$ & \multicolumn{2}{|c|}{$\begin{array}{r}37.2 \\
<0.05\end{array}$} & \multicolumn{2}{|c|}{$\begin{array}{l}40.8 \\
<0.01\end{array}$} & \multicolumn{2}{|c|}{$\begin{array}{r}21.3 \\
\text { NS }\end{array}$} & \multicolumn{2}{|c|}{$\begin{array}{r}19.5 \\
\text { NS }\end{array}$} & \multicolumn{2}{|c|}{$\begin{array}{l}21.3 \\
\text { NS }\end{array}$} \\
\hline $\begin{array}{l}\text { Location and type of } f \\
\chi^{2}(d f=16)\end{array}$ & \multicolumn{2}{|c|}{$\begin{array}{l}18.8 \\
\text { NS }\end{array}$} & \multicolumn{2}{|c|}{$\begin{array}{l}12.2 \\
\text { NS }\end{array}$} & \multicolumn{2}{|c|}{$\begin{array}{r}15.5 \\
\text { NS }\end{array}$} & \multicolumn{2}{|c|}{$\begin{array}{l}17.0 \\
<0.05\end{array}$} & \multicolumn{2}{|c|}{$\begin{array}{l}16.7 \\
\text { NS }\end{array}$} \\
\hline $\begin{array}{l}\text { Size of farm and type of } \\
\chi^{2}(d f=16)\end{array}$ & $\begin{array}{ll}14 . \\
\text { NS }\end{array}$ & & $\begin{array}{c}15 \\
N\end{array}$ & & $\stackrel{24}{N}$ & & & & 10 & \\
\hline
\end{tabular}

a Reference group.

Table 5. Proportion of male farmers (35-64 years) in Finland in 1979 who had ever or never smoked by type of production and farm size. ${ }^{a}$

\begin{tabular}{|c|c|c|c|c|c|c|c|c|c|c|}
\hline \multirow{3}{*}{$\begin{array}{l}\text { Size of farm (ha) } \\
\text { (cultivated land, } \\
\text { own or } \\
\text { rented) }\end{array}$} & \multicolumn{5}{|c|}{ Livestock production } & \multicolumn{5}{|c|}{ Grain production } \\
\hline & \multirow{2}{*}{$N$} & \multicolumn{4}{|c|}{ Smokers } & \multirow{2}{*}{$\mathrm{N}$} & \multicolumn{4}{|c|}{ Smokers } \\
\hline & & $\begin{array}{c}\text { Never } \\
(\%)\end{array}$ & $\begin{array}{l}\text { Ever } \\
(\%)\end{array}$ & $\begin{array}{c}\text { No } \\
\text { information } \\
(\%)\end{array}$ & $\begin{array}{l}\text { Total } \\
(\%)\end{array}$ & & $\begin{array}{c}\text { Never } \\
(\%)\end{array}$ & $\begin{array}{l}\text { Ever } \\
(\%)\end{array}$ & $\begin{array}{c}\text { No } \\
\text { information } \\
(\%)\end{array}$ & $\begin{array}{c}\text { Total } \\
(\%)\end{array}$ \\
\hline $0-4.9$ & 225 & 24.4 & 73.3 & 2.2 & 100 & 46 & 23.9 & 73.9 & 2.2 & 100 \\
\hline $5-9.9$ & 1144 & 29.4 & 68.9 & 1.7 & 100 & 108 & 42.6 & 56.5 & 0.9 & 100 \\
\hline $10-14.9$ & 782 & 36.3 & 61.4 & 2.3 & 100 & 71 & 43.7 & 56.3 & 0.0 & 100 \\
\hline $15-19.9$ & 427 & 42.9 & 55.3 & 1.9 & 100 & 37 & 51.4 & 48.6 & 0.0 & 100 \\
\hline$\geq 20$ & 507 & 46.7 & 52.3 & 1.0 & 100 & 195 & 51.8 & 47.2 & 1.0 & 100 \\
\hline
\end{tabular}

a Based on the farmers' health survey (by questionnaire) in 1979, made by the Research Institute for Social Security of the Social Insurance Institution of Finland in collaboration with the Kuopio Regional Institute of Occupational Health and the National Board of Health.

the relative risk of disability pension is higher among those with small farms than among other farmers, even in the register of the same farm population (12).

The proportion of farmers who have ever smoked was clearly higher among those with small farms than among the rest of the farm population (table 5). Evidently the high relative risk of death due to respiratory diseases, neoplasms, and also cardiovascular diseases among men with small farms is connected with the higher proportion of smokers in this group. 
The average proportion of smokers among Finnish farmers was lower than among the whole male population (table 5). For farmers the proportion of those who had ever smoked (1978-1980) was 68.9, but for industrial workers the corresponding figure was 82.7 , and for those in the service sector it was $75.6(8)$.

In addition, even among men with small farms, for whom the proportion of smokers was highest, the proportion of those who had ever smoked was lower than that of the total population at the same time (table 5) (8). Smoking therefore cannot explain the high relative risk of respiratory deaths among men with small farms or among the whole farming population.

Farmers, especially on small livestock-producing farms, are exposed to various organic and microbial dusts and endotoxins $(9,10,14)$, which, it has been claimed, cause the high morbidity from respiratory diseases (asthma, farmer's lung and chronic bronchitis) among farmers (6). This exposure explains, to some extent, the high relative risk of respiratory deaths among male farmers and suggests that the high mortality rate due to respiratory diseases among farmers is work-related.

In analyses of mortality differences by type of farm production, there is an additional problem, namely, "selection." Although, in livestock production, farmers are probably more exposed to different organic and microbial dusts, their mortality due to respiratory diseases was not higher than the mortality of farmers in the group with no animals. This finding might, however, be due to the fact that the farmers who did not have animals at the beginning of the follow-up period had had animals previously, but, owing to some respiratory problems, they had probably changed the type of production - for example, from dairy farming to grain crops.

Selection might also explain the high mortality due to accidents, poisonings and violence in the group with no animals. In an additional analysis, it was shown that both mortality due to transport accidents and that due to suicides was higher in this group.

The interaction effects between variables were small. At this stage of our analysis, however, we have to bear in mind that, when the different interactions were analyzed, the number of deaths was small.

The mortality of men with small farms was shown to be associated with the life-style of these men (smoking). Apparently the differences in mortality between small-farm owners and other farmers could also be partly work-related. General socioeconomic factors, such as quality of housing, type of diet, and the general "heavy burden of life" might also partly explain the observed difference between men with small farms and other farmers.

We are now conducting a series of epidemiologic studies with the objective of explaining the relation of dust exposures at work (organic dusts, microbial dusts, endotoxins) and respiratory morbidity among Finnish farmers.

\section{Acknowledgments}

This study was supported by a grant from the Yrjö Jansson Foundation.

\section{References}

1. Armitage P. Statistical methods in medical research. Blackwell Scientific Publications, London 1971.

2. Aromaa A. Viljelijäväestön terveydentila tilastotiedoin ja väestötutkimuksin arvioituna [The health of the Finnish farming population: An analysis of statistical and demographic data]. Sosiaalivakuutus 9-10 (1979) 262-275.

3. Baker RJ, Nelder JA. General linear interactive modelling (GLIM), release 3. Numerical Algorithms Group, Oxford 1978.

4. Blair A, Malker H, Cantos KP, Burmeister L, Wiklund K. Cancer among farmers: A review. Scand J Work Environ Health 11 (1985) 397-407.

5. Holford TR. The analysis of rates and survivorship using log-linear models. Biometrics 36 (1980) 299-305.

6. Husman K, Koskenvuo M, Kaprio I, Terho EO, Vohlonen I. Role of environment in the development of chronic bronchitis. Eur J Respir Dis (in press).

7. Karisto A. Hyvinvointi ja sairauden ongelmat [Welfare and the problems of illness]. Social Insurance Institution, Helsinki 1984. (Publications of the Social Insurance Institution of Finland, M: 46) (English summary).

8. Koskinen S, Puska P, Valkonen T. Terveyskäyttäytyminen keski-ikäisen väestön osaryhmissä 1978-80 [Health behaviour among middle-age population 1978 - 80]. National Public Health Laboratory, Helsinki 1981. (Publications of National Public Health Laboratory $\mathrm{B} 1 / 1981$ ).

9. Kotimaa M, Terho EO, Husman K. Airborne moulds and actinomycetes in the work environment of farmers. Eur J Respir Dis (in press).

10. Louhelainen K, Kangas J, Husman K, Terho EO. Total concentration of dust in the air during farm work. Eur J Respir Dis (in press).

11. Notkola V. Living conditions in childhood and coronary heart disease in adulthood: A mortality and morbidity study in two areas of Finland. Societas Scientiarum Fennica, Helsinki 1985. (Commentationes Scientiarum Socialium 29).

12. Notkola V, Husman $\mathrm{K}$, Laukkanen V. The incidence of disability pensions among farmers in Finland in 1979-1983. Sosiaalilääketieteellinen Aikakauslehti 23 (1986).

13. Population and Housing Census. Official statistics of Finland VI C: 106. Helsinki 1983.

14. Rylander R. Role of endotoxins in the pathogenesis of respiratory disorders. Eur J Respir Dis (in press).

15. Sauli H. Oecupational mortality in $1971-75$. Central Statistical Office of Finland. Helsinki 1979. (Studies no 54).

16. Vohlonen I, Husman K, Kalimo E, Nuutinen J, Tupi K, Virolainen R. Viljelijöiden työterveyshuolto: Kokeiluun perustuva tutkimus 1979-83. [Occupational health services for farmers: A study based on an experiment in 1979-83]. Social Insurance Institution, Helsinki (Publications of the Social Insurance Institution A: 21) (English summary).

Received for publication: 8 July 1986 